This is the version of the chapter accepted for publication in: Soundings: a journal of politics and culture, 62. pp. 121-137 (2016), published by Lawrence \& Wishart

https://doi.org/10.3898/136266216818497712

Re-use is subject to the publisher's terms and conditions

This version downloaded from SOAS Research Online: http://eprints.soas.ac.uk/36728

\title{
Militarism or internationalism? British foreign policy at a crossroads by David Wearing
}

Published in, 'Soundings: A Journal of Politics and Culture', issue 62, April 2016, p121-137

The two recent House of Commons votes on military action in Syria, in August 2013 and December 2015, hint at a potential crisis of legitimacy brewing in the realm of British foreign policy. On the first occasion, the vote not to authorise military action against the Bashar Al-Assad regime, and the wider public opposition it reflected, triggered a sort of meltdown amongst the liberal interventionist community, with howls of existential angst about Britain's future role in the world, and dark warnings of the dangers of retreating from 'internationalism' into 'isolationism'.

The December 2015 Commons vote on intervention against the self-styled 'Islamic State', saw MPs voting in favour. A major subtext of the drama was the universal antipathy in Westminster and Fleet Street towards the new leader of the Labour Party, the anti-imperialist and anti-militarist Jeremy Corbyn, the climax of which was the speech given by Corbyn's shadow foreign secretary Hilary Benn, where Benn sided with the government. The adulation Benn received on both sides of the House and across the media was out of all proportion to the quality of a speech that was comprised of four parts platitudes and strawmen (ISIS are evil and must be defeated) to one part poor judgement (for example in glossing over the government's deliberate exaggeration of the number of available allies on the ground in Syria). What Benn was really being praised for was fulfilling the proper role of the leader of the Labour Party on such issues, which is to bathe British militarism in the soft glow of enlightened, liberal rhetoric.

The anxiety about the 2013 vote, and the gratitude for Benn's speech, are both attributable to a growing problem faced by the political class. Put simply, the dominant narratives and themes that they have been using for many years to make sense of and justify Britain's role in the world, particularly in the Middle East, are now beginning to unravel. The hegemonic discourse that casts the British state, with its military power to the fore, as a benign force for good, has become markedly less convincing in the period following the commencement of the 'war on terror' in 2001, through the Arab uprisings of 2011, and onwards. This in turn threatens to impede the British state's ability to secure the requisite political consent for the projection of its military power in the future. Conversely, for those who seek to pursue a transformative project from the left, space has now opened up for a counter-narrative that not only diagnoses the causes of this potential crisis, but, crucially, also proposes a different, better, way for Britain to engage with the rest of the world.

The next section of this article will describe the features of the liberal hegemonic discourse around British foreign policy that emerged after the end of the Cold War. The stresses and strains that were put on this narrative by the 'war on terror' and the Arab uprisings will then be examined, along with the reasons to believe that these pressures will only increase in the years to come, as events in the Middle East stretch Western policy towards breaking point. Finally, the features of a different approach to Britain's relationship with the world will be briefly set out - one that, of course, could only be brought about as the result of a dramatic change in British politics. 


\section{Empire and its narratives}

At any given historical juncture, the international projection of western military, economic and political power has been accompanied by a justificatory set of narratives. The role of this hegemonic discourse, which sets the parameters for discussion of individual issues and policies, is to cast the imperial project in a favourable light and secure the involvement, cooperation and consent of politicians, state officials, journalists, scholars and a sufficient proportion of the general public to ensure the project's political sustainability. In the nineteenth century, this metanarrative involved frankly expressed notions of ethnic, cultural and moral superiority, justifying various instances of settler colonialism, and other forms of direct military and administrative control over a large proportion of the global south. After the Second World War, the threat of communism was used to rationalise extensive efforts to thwart independent nationalist movements and governments in the south, despite these frequently having little or no relationship with Moscow's brutal but constrained influence. After the fall of the Berlin Wall, the West had to tell itself a new story about the nature of its role in the world.

The ejection of Iraqi occupation forces from Kuwait in 1991 by a broad, US-led military coalition acting under a UN Security Council mandate provided the starting point for the new narrative. The Gulf War acted as a demonstration not only of Washington's unrivalled military might but also of its ability to secure broad international legitimacy and support for the exertion of its will. With the Cold War over, US global hegemony would - so the story went - heralded a benign new liberal era, with Washington acting through various multilateral institutions on the economic and diplomatic fronts to promote democracy and free markets and bring a new age of global prosperity and security. Underwriting all this would be the peerless strength of the US military and its allies, which under the new narrative was increasingly portrayed in dangerously simplistic terms as a tool for liberal humanitarianism.

Tony Blair was among the first to seize upon the possibilities presented by these new circumstances. From 1999 onwards, Blair and others began to articulate an 'interventionist' discourse whose key motifs are now familiar: that the horrors of Rwanda and Srebrenica in the 1990s were attributable to a failure of the 'international community' to intervene; that intervention in Kosovo in 1999 had proven that Western military power could be a powerful force for good in the world; and that this power should be deployed more readily in future, even at the expense of state sovereignty and without UN authorisation, where deemed appropriate. ${ }^{1}$

Of course, this set of propositions contained several problems. First of all, such interventions would in practice be carried out not by the 'international community' but by the NATO states led by the US, since only they possessed the requisite military power to effectively appoint themselves the world's policemen. But more problematic still was the assumption at the heart of the new liberal discourse: namely that the US and its allies were qualified altruistic or humanitarian actors. In fact, their credentials in this regard were questionable, to put it mildly. One of the greatest humanitarian

\footnotetext{
${ }^{1}$ T. Blair, 'Doctrine of the International Community', 24 April 1999 http://webarchive.nationalarchives.gov.uk/+/www.number10.gov.uk/Page1297 ; J. Kampfner, 'Blair's Wars', Free Press, London 2004.
} 
disasters of the 1990s occurred in Iraq where hundreds of thousands died, up to half a million of them infant children, as a result of US and UK sanctions, a cost that was understood and accepted by the governments responsible. ${ }^{2}$ And while the brutality of strategic opponents like Slobodan Milosevic was opposed to various degrees, the brutality of, for example, Russia (a 'partner' during the 1990s) in Chechnya was indulged, and that of allied Turkey towards its Kurdish population was actively supported $^{3}$.

In other words, the right of the 'international community' to carry out 'humanitarian intervention' added up to little more than the right of Western states with a proven disregard for human life to exert themselves militarily as they saw fit, without legal constraint, and wherever a useful moral pretext could be articulated. This was the prevailing foreign policy discourse of the age on the morning of 11 September 2001, when hijacked US airliners crashed into their targets in Washington and New York.

\section{Inescapable contradictions: the 9/11 decade and the Arab uprisings}

A series of events over the subsequent years, and two experiences in particular, have made the liberal story a harder one to tell in a convincing way. The first of these experiences was the 'war on terror' of the Bush-Blair years and the second was the Arab uprisings that began in 2011 and the regional crisis that ensued. Throughout this period, liberal interventionist rhetoric has been overlaid with a new language of civilisational conflict that echoed earlier imperial periods, but which has proven less and less capable, over time, of containing the contradictions between the narrative and the facts.

While the original invasion and occupation of Afghanistan was relatively straightforward for Washington and London to justify after the atrocity of 9/11, the invasion of Iraq eighteen months later was a different matter entirely. The slippery, duplicitous nature of the case for war made the invasion look increasingly like aggression masquerading as self defence, and the failure to secure public and international support exposed the British and American states as pursuing their own narrow agendas rather than a more general, enlightened purpose. After the Saddam regime was quickly defeated, the brutality of the occupying forces - mostly notably in the destruction of the city Fallujah and in the torture and humiliation at Abu Ghraib prison - provided a chilling rebuke to the assumption of benign Western military power upon which the entire hegemonic discourse of western foreign policy is founded.

The contradictions ran right through the key components of the 'war on terror': from the kidnapping and torture of the US rendition programme, through detention without due process at Guantanamo Bay, to the extrajudicial, extraterritorial execution programme carried out via drone strikes, the extension of state violence was justified with the flimsiest of legalistic veneers. Meanwhile, Israel repeatedly shocked the world with its indiscriminate bombings of Lebanon and Gaza, and persisted in its refusal to allow the occupied Palestinians their freedom and independence. Clashes between high-minded rhetoric and gruesome reality were the recurring theme from

\footnotetext{
${ }^{2}$ M. Curtis, "Web Of Deceit: Britain's Real Role in the World", Vintage: London, 2003, pp28-33

${ }^{3}$ Ibid, pp157-79
} 
Israel's western allies, and never more so than in summer 2006, when, against a backdrop of Israeli war crimes carried out in Lebanon with US-supplied weapons, Secretary of State Condoleezza Rice acclaimed 'the birth pangs of a new Middle East'.

After the Weapons of Mass Destruction pretext for the Iraq invasion fell apart, the emphasis changed to 'democracy promotion' as a justification for the Bush administration's policies, both in Iraq and the wider Middle East. This however only served to draw attention to one of the most glaring contradictions in the discourse, namely the extensive, material and longstanding support given by the ostensibly liberal, democratic West to some of the most repressive, exploitative regimes in the region. The hypocrisy was only underlined when, for the crime of voting the wrong way in a free election in January 2006, the occupied Palestinians were punished with sanctions, an attempted coup, and then the immiserating siege of Gaza.

Not long after Bush and Blair departed the stage, the chasm between discourse and actual policy opened up once more as the Middle East was gripped by a wave of popular uprisings against political repression and social injustice in the winter of 2010-11. For all the prior talk of 'democracy promotion' amongst Western politicians, journalists and intellectuals, the inescapable fact was that it was the people of the region who were now rising up to demand their rights, against many of the same regimes that the West had been backing and arming to the teeth for decades. The issue was not that Britain and the US had failed to promote democracy with sufficient vigour or sensible application. It was that, in connivance with their local allies, they had deliberately constructed formidable obstacles to the processes of social change and political pressure that could help bring democracy about. The suggestion at the time from genuine democrats that the West had found itself on the wrong side of history was born of the hope that the events of early 2011 would bring lasting changes in the region. For now, we can only say that the Arab uprisings have placed Western foreign policy, once again, on the wrong side of its own legitimating ideology.

\section{Widening contradictions: the decade to come}

There is no reason to believe that these contradictions will resolve themselves or even fade back from the headlines and from public consciousness in the years ahead. On the contrary, the nature of the West's strategic commitments in the Middle East, coupled with the grim trajectory that the region is now on, raise the strong possibility that those contradictions will become even more pronounced, and almost impossible to ignore.

To get a sense of how these dynamics are likely to play out, it is important first to establish a clear understanding of the strategic commitments shaping British foreign policy in the Middle East. We can then move on to examine how these commitments will likely drag the British state into a series of foreign policy crises, as long-deferred changes unfold in the region according to their own remorseless logic.

\footnotetext{
${ }^{4}$ J. Beale, 'Diary: Rice's Mid-East mission', BBC News, 26 July 2006

http://news.bbc.co.uk/1/hi/world/middle east/5205164.stm
} 
The overarching strategic priority for UK foreign policy has remained largely unchanged for a century or more: the maximisation of the prestige, power and influence of the British state, and the maintenance and extension of a global political and economic order conducive to the commercial interests of British capital. This, as I have argued previously, should be understood as quite distinct from any broader 'national interest' that may be invoked to legitimise state policy.

While these primary aims remain largely constant, what has changed over the decades is the international environment in which they are pursued, and the capacity of the British state to pursue them. By the end of World War Two, it was clear that only the global hegemony of the United States could secure the kind of world order sought by British policymakers, and that London would be reduced to playing as prominent a complementary role as it was capable of (particularly on the military and diplomatic front), and to maximising its own state and commercial benefits, within that larger framework. Britain would still be in the business of imperialism, but no longer as chairman and chief executive.

By now, the Middle East was a central strategic concern - an inescapable and overriding priority for any state interested in global power. The region's enormous energy reserves had become the lifeblood of industrial capitalism, with changes in supply and price having a dramatic effect on the health of the world economy. In addition, the seemingly limitless revenues accruing to the producer states from the early 1970s onwards became highly sought after by the financial industry, states hungry for investment, and arms industries on the lookout for wealthy, insecure customers.

The question then for the US and UK was one of power and influence over the major energy producing region of the world, rather than merely access to these reserves for their own needs. The deep alliances forged with the regimes sitting atop the oil and gas fields of the Middle East, and with their immediate neighbours, have been a major strategic advantage for the US and UK over rival powers, and the rest of the world. Any disruption to those relationships has been simply unthinkable, given the magnitude of the stakes. Recent talk of a shale oil revolution making the US energy independent, and thus free to escape from its Middle Eastern entanglements, fundamentally misunderstands the importance to imperial power of this complex set of interests (but then, of course, acknowledgment of the imperial nature of US power is, by definition, impossible within the parameters of the hegemonic liberal discourse).

What does all this mean for British foreign policy in the Middle East today? Essentially that protecting the regional status quo to the greatest extent possible, or keeping any changes confined within strict limits, is nothing less than a strategic imperative.

\footnotetext{
${ }^{5}$ D. Wearing, 'Critical Perspectives on the Concept of the 'National Interest': American Imperialism, British Foreign Policy and the Middle East', in T. Edmunds, J. Gaskarth \& R. Porter (eds), British Foreign Policy and the National Interest: Identity, Strategy and Security, Palgrave Macmillan, London 2014.
} 
Two important points are derived from this. First, British arms supplies must continue to flow to allied regimes, not only to keep those regimes in place, but also to keep in business the national arms industry that is essential to Britain's status as a military power. With arms sales to the rest of the world in long-term decline, the Gulf monarchies' importance in this regard only increases. Second, in terms of policing this strategically vital and increasingly unstable part of the world, British military credibility must be maintained in order to preserve the prestige of the British state, not least in the eyes of the senior officers in Washington. The British must be at the Americans' side when ad hoc coalitions for 'intervention' are put together, and must play a serious and effective role.

Now consider the landscape in which London will be attempting to honour these commitments. As Gilbert Achcar has explained in his indispensable analysis of the roots of the Arab uprisings, there is next to no prospect of the turmoil in the Middle East resolving itself any time soon. ${ }^{6}$ The authoritarian, crony capitalist model that appears in various forms across the region has run out of road, with the conditions and future prospects of the people living under these regimes now long past the point of being tolerable. By supporting autocratic regimes in the belief that they were buying 'stability' (on their terms), all the West achieved was a deferral of the inevitable days of reckoning, and a steady build-up of the pressures beneath the surface, which finally and inevitably burst through five years ago.

Hidden decay and decomposition have in many cases now given way to full blown collapse. Libya, Syria and Yemen are officially failed states, Iraq partially so. The coup in Egypt, and subsequent massacres of the deposed government's supporters, have predictably triggered a full-scale internal conflict with armed groups, including ISIS, fought by a regime which, like the rest of its neighbours, has no answers to the chronic economic and political problems that lie at the root of the crisis. Bahrain exists in a permanent state of armed repression, while the Saudi family's paranoia scales new heights, as it lashes out ever more violently and recklessly. Lebanon and Jordan strain under the weight of huge refugee influxes from Syria, Palestinians are confronted with new levels of hopelessness, and Israeli politics slides further and further to the right with every parliamentary election. Anarchic, ungoverned spaces open up everywhere, quickly filled by the pitiless rage of the so-called 'Islamic State' and the vicious calculations of its ex-Baathist officer class.

It is into this environment that the British state will be exporting its arms, intervening militarily, and extending its support to allied autocrats, while the denizens of Westminster and Fleet Street tell themselves stories of enlightened liberal internationalism, and sensible, grown-up approaches to questions of security. Clearly this will present problems.

Containing political disquiet about arms sales to Saudi Arabia had been relatively easy back when the region was more or less stable, repression was kept out of sight, and the Saudi military, with its huge fleet of British fighter jets, was thought to be little more than a white elephant, its weaponry gathering dust and probably never to be used. But those days are gone. In recent years, the Saudis have helped another

\footnotetext{
${ }^{6}$ G. Achcar, 'The People Want: A Radical Exploration of the Arab Uprising', Saqi, London 2013.
} 
customer of the British arms industry, Bahrain, to violently crush a peaceful, nonsectarian pro-democracy movement, and sharply ramped up internal violence against all threats to monarchical rule, including peaceful dissent, which is now classified by the Saudis as a form of terrorism and punishable, in the final instance, by death. ${ }^{78}$

As a result, the UK-Saudi alliance - near impossible to justify or reconcile within the hegemonic liberal discourse on foreign policy, for reasons that hardly need to be spelled out - is now back in the headlines, and is likely to remain there. If anything, there is real scope for controversy to increase, given Britain's involvement in the Saudis' devastating war in Yemen. As of summer 2015, the UN ranked Yemen within its highest category of humanitarian disaster, with 21 million people in need of aid 82 per cent of the population - as a Saudi-led coalition that includes some of the richest states in the region placed one of the poorest under a punitive blockade. Tens of thousands of people were made refugees or became internally displaced, with around 3000 civilians killed by the start of 2016, mostly in air strikes by Saudi-led forces. These are often British-made jets dropping British-made bombs, with British personnel giving technical and logistical support in the background. Leading human rights organisations such as Amnesty International and Human Rights Watch have documented numerous instances of potential war crimes. ${ }^{9}$

The failure of the Saudi-led coalition to achieve its objectives after several months merely ensures the continuation of the war, lest 'credibility' be squandered in an embarrassing retreat. Such is the logic of organised violence, a logic which also applies to British militarism, given the record of recent years. Britain's wars in Afghanistan, Iraq and Libya have all been demonstrable failures on their own terms, (putting aside questions of whether we agree with those terms or not). In the occupations of Iraq and Afghanistan, Britain was allocated specific tasks to perform, in Basra and Helmand provinces respectively, and failed on both occasions. With every failure comes the urge to put things right, to restore 'credibility', to find a new battlefield and stage a suitable demonstration of strength and virility. And every such new opportunity constitutes a new opportunity for failure, and for the cycle to be renewed. The militaristic reflexes of the British political class are by now so ingrained that the possibility that problems, even ones involving violence, might not have a primarily military solution, is more or less incomprehensible, as was seen in the response to the terrorist atrocities in Paris in December 2015.

\footnotetext{
${ }^{7}$ Campaign Against Arms Trade, 'Saudi Arabia uses UK-made armoured vehicles in Bahrain crackdown on democracy protesters', 16 March 2011 https://www.caat.org.uk/media/press-releases/2011-03-16

${ }^{8}$ Human Rights Watch, 'Saudi Arabia: New Terrorism Regulations Assault Rights', 20 March 2014 https://www.hrw.org/news/2014/03/20/saudi-arabia-new-terrorism-regulations-assault-rights ; Amnesty International, 'Shia cleric among 47 executed by Saudi Arabia in a single day', 2 January 2016 https://www.amnesty.org/en/latest/news/2016/01/shia-cleric-among-47-executed-by-saudi-arabia-in-asingle-day/

${ }^{9}$ Amnesty International, 'Yemen: Call for Suspension of Arms Transfers to Coalition and Accountability for War Crimes', 7 October 2015 https://www.amnesty.org/en/press-releases/2015/10/yemen-call-forsuspension-of-arms-transfers-to-coalition-and-accountability-for-war-crimes/ ; Human Rights Watch, 'Yemen: Coalition Drops Cluster Bombs in Capital', 7 January 2016 https://www.hrw.org/news/2016/01/07/yemen-coalition-drops-cluster-bombs-capital-0
} 
So the downward spiral is likely to continue. The violence of local states, often fuelled by Western arms and support, will continue to alienate populations from their governments, destroy economies and infrastructure, and create vacuums filled by fanatics. As the situation worsens, state violence will increase, as will the supply of arms, and the likelihood of direct Western intervention. Whoever succeeds Barack Obama in the White House is unlikely to share his relative caution on such matters, thus increasing the probability of deeper interventions, with London trotting along behind. The terrorist threat to the West, if anything worse now than it was the day after 9/11, will continue, perhaps escalate, and 'war-on-terror' responses - fifteen, twenty years on from 2001, and with no results to speak of - will lose further credibility.

Consider the following hypothetical scenario, which has become a good deal less than implausible in the current conditions. One of British liberalism's most embarrassing allies, Saudi Arabia for example, descends into full-scale civil war and London sides with the regime, placing it in an equivalent role to Moscow in the latter's support for Bashar al-Assad. There can be little doubt of what the Saudi regime is capable of doing with its back to the wall, and in defence of the throne. In those circumstances, the liberal narrative on UK foreign policy would be reduced to little more than a profoundly unfunny joke.

Taking all this into account, it is difficult to envisage how the elite discourse that emerged around British foreign policy in the 1990s, and which has taken such a battering through the early years of the twenty-first century, can escape further and deeper humiliations in the years to come. As the various conflicts in the Middle East deepen, it will become harder to portray the chief enablers of the likes of Saudi Arabia as champions of liberal, humanitarian values, and harder to portray the military power of the British state as a benign force for good, let alone a force competent to execute the tasks it sets itself and demands public consent for. The tales that power tells itself and others in order to secure that consent will be less convincing in the face of overwhelming contradictory evidence and experience, and this will impact upon British foreign policy as a whole.

\section{The crisis of consent}

Liberal interventionists were expressing anxieties about a brewing crisis of consent around British military action even before the Syria vote of August 2013. ${ }^{10}$ That experience seemed to confirm their fears of increased constraints on the use of state violence being imposed by significant sections of the population, and from more cautious members of the political class. A poll conducted in the week of the Commons vote found that the experiences of Libya, Afghanistan and Iraq had made

\footnotetext{
$10 \mathrm{~J}$. Freedland, 'Syria is not Iraq. And it is not always wrong to intervene', The Guardian, 10 February 2012 http://www.theguardian.com/commentisfree/2012/feb/10/syria-not-iraq-wrong-intervene ; $M$. Kettle, 'Cameron and Obama ended the neocon era. But the era of Assad goes on', The Guardian, 14 March 2012 http://www.theguardian.com/commentisfree/2012/mar/14/cameron-obama-ended-neoconera ; See also my response to these pieces, D.Wearing, 'In defence of 'Iraq syndrome': liberal values never drive intervention', The Guardian, 3 April 2012 http://www.theguardian.com/commentisfree/2012/apr/03/in-defence-of-iraq-syndrome
} 
59 per cent of the public less supportive of future interventions ( 36 per cent were 'a lot less supportive', 12 per cent were more supportive, and 4 per cent 'a lot more supportive ${ }^{11}$ ). While the invasion of Iraq had demonstrated the ability of decisionmakers to insulate themselves from popular opinion, those barriers were to some extent breaking down. Labour MPs - and some Tories - reported 'very strong opposition' to intervention amongst the public. ${ }^{12}$ After the Blair years, politicians seemed increasingly aware of the political costs of supporting risky military adventures.

The response to the vote from interventionists was one of bitter dismay. The Times described it as 'a disaster for the country, which turned its back on its tradition of standing up to tyranny'. ${ }^{13}$ According to an editorial, the vote had 'provided encouragement to despots and tyrants everywhere', and there was a need to ensure that the episode did not 'prove the end of Britain's role as an outward-looking nation that acts as a defender of liberty and law across the globe'. Former leader of the Liberal Democrats Paddy Ashdown wrote that: 'Great Britain, which led in international law and engagement, will lead a retreat from these ideals towards a new mood of growing isolationism'. Labour had 'placed in question its proud tradition of internationalism', while there was 'a dangerous mood of isolationism running in our country' more generally. ${ }^{14}$

For Times columnist David Aaronovitch, the vote was indicative of the fact that: 'We are living through a bad-tempered and isolationist moment in British politics ... Many want to stop the world. No entanglements. Fewer immigrants. Stop this, don't build that. Get out of Europe'. ${ }^{15}$ In the Observer, Nick Cohen speculated that 'the majority of the public ... think, I guess, that Arabs and Muslims are all the same. They all want to kill each other. They are all barbarians. "Why should we try to save them? They will only turn on us if we do", 16

In January 2014, senior figures at the Ministry of Defence told the Guardian that an acknowledged war-weariness amongst the general public was influencing the next

\footnotetext{
${ }^{11}$ T. Helm., 'Poll finds 60 per cent of British public oppose UK military action against Syria', The Observer, 31 August 2013 http://www.theguardian.com/politics/2013/aug/31/poll-british-militaryaction-syria

${ }^{12}$ T.Helm., 'How Cameron lost the battle with his party - and the country', The Observer, 1 September 2013 http://www.theguardian.com/politics/2013/sep/01/how-cameron-lost-battle-syria-vote

${ }^{13}$ Editorial, 'The Tragedy of the Commons', The Times, 30 August 2013 http://www.thetimes.co.uk/tto/opinion/leaders/article3855555.ece
}

${ }^{14}$ P.Ashdown., 'After the Syria vote, Britain must not sleepwalk into isolationism', The Guardian, 31 August 2013 http://www.theguardian.com/commentisfree/2013/aug/31/syria-vote-britain-paddyashdown

${ }^{15}$ D. Aaronovitch., 'Ed Miliband is no leader. He is a vulture', The Times, 5 September 2013 http://www.thetimes.co.uk/tto/opinion/columnists/davidaaronovitch/article3860789.ece

${ }^{16}$ N. Cohen., 'Don't look to Ed Miliband for moral leadership', The Observer, 7 September 2013 http://www.theguardian.com/commentisfree/2013/sep/07/syria-ed-miliband-no-moral-courage 
two strategic defence reviews. In addition to the experiences of recent interventions, the $\mathrm{MoD}$ also 'sensed a resistance in an increasingly diverse nation to see British troops deployed in countries from which UK citizens, or their families, once came'. ${ }^{17}$ In other words, one factor in public resistance to the use of military force abroad was a growing international - not parochial - perspective within public opinion. A poll conducted the week after the vote in parliament demonstrated that public opposition was due to concern that armed action (and lack of UN authorisation) would make matters worse, and that indifference to the plight of Syrians was a minority view. ${ }^{18}$

The worries of the military establishment became more and more openly expressed. In September 2015, Sir Nick Houghton, the chief of defence staff, bemoaned the fact that 'we are experiencing ever greater constraints on our freedom to use force', specifically identifying a lack of public support as one such constraint, and the resulting difficulties in securing parliamentary approval. The concern was that: 'if a nation's assumed willingness to commit to the use of force is only in the face of [a threat to] national survival, then we encourage rather than deter revisionist states and their own ambitions' - a clear admission that 'defence' policy is not about self defence but about the geopolitical policing of the world. ${ }^{19}$

\section{Whose 'internationalism'?}

Liberal interventionists have framed the breakdown of consent in terms of (their) internationalism versus (the left's or the public's) isolationism, but they are conflating their militarism and neoliberal imperialism with genuine internationalism. After all, if internationalism means anything, it means honouring and protecting universal human rights, not drone strikes, extraordinary rendition and the world's great military powers arming the world's worst tyrannies as they act as a roadblock to democracy and commit war crimes in places like Yemen. A genuine internationalism would also mean, for example, prioritising diplomacy and conflict resolution wherever possible, rather than reflexive militarism and conflict exacerbation.

Indeed, by reclaiming the concept of internationalism from its misuse within the hitherto hegemonic discourse, it becomes possible to create the conceptual, legitimising framework for a new counter-narrative on British foreign policy as a whole, not just in the Middle East. As the dominant narrative is progressively undermined in the light of events, political space opens up to move from critique to the articulation of something more solid and compelling, in terms of concrete policy proposals.

\footnotetext{
${ }^{17}$ P. Wintour., 'Multicultural Britain rejecting foreign conflict, MoD admits', The Guardian, 23 January 2014 http://www.theguardian.com/uk-news/2014/jan/22/multicultural-britain-foreign-conflict-mod

${ }^{18}$ P. Kellner., Voters Tell Cameron: Don't Bomb Syria, But Do Help Obama', YouGov, 1 September 2013 http://yougov.co.uk/news/2013/09/01/voters-tell-cameron-dont-bomb-syria-do-help-obama/ See full survey results here http://cdn.yougov.com/cumulus_uploads/document/e3mn8j0hh5/YouGov_SundayTimes_VI_Syria_13 0831.pdf

${ }^{19}$ E. MacAskill, 'Chief of defence staff concerned over lack of UK military support', The Guardian, 15 September 2015 http://www.theguardian.com/uk-news/2015/sep/15/chief-of-defence-staff-concernedover-lack-of-uk-military-support
} 
The point is not that large sections of the public now buy into an anti-imperialist, antimilitarist reading of UK foreign policy. Indeed, majority or plurality support has been forthcoming for some recent interventions. Rather, the point is that this support is becoming harder to secure due to doubts and misgivings that are unlikely to be assuaged in the years to come. This makes it possible to gain a hearing for a counternarrative that addresses public concerns seriously, with proper analysis, and begins a conversation about what a genuinely internationalist foreign policy would look like.

\section{Towards a new British internationalism}

For this counter-narrative to be compelling, it must offer not only a critique of the present but a contrastingly attractive alternative future. Here then are some initial policy suggestions that could form part of a new, progressive internationalism. A lot of detailed, collaborative work will be required to develop each of these ideas to the full. For now, the point is simply to show that several separate, important issues can potentially be brought together under the banner of a truly internationalist foreign policy.

The first suggestion addresses the greatest long-term threat to international security: global warming. The considerable resources, workforce, technical skills and state subsidies currently employed in the British arms industry should be diverted into the development of renewable energy and energy efficiency projects. ${ }^{20}$ This can be framed both as national mobilisation to counter most serious threat to humanity since World War Two, and as part of a new high-tech, future oriented industrial policy aimed at creating secure, decently paid jobs, boosting exports, and thus reducing the British economy's reliance on the arms trade and the financial sector.

The second policy suggestion addresses the other major threat to international security. As the Bulletin of Atomic Scientists Science and Security Board recently noted, 'global nuclear weapons modernizations, and outsized nuclear weapons arsenals pose extraordinary and undeniable threats to the continued existence of humanity, ${ }^{21}$. The current complacency about the danger of an accident or miscalculation being made by a nuclear state in the midst of an international crisis is profoundly misjudged, and could have unthinkable costs. As a step towards nuclear disarmament Britain should therefore cancel the renewal of Trident, and take the initiative in convening an urgent summit of the existing nuclear powers to agree a rapid honouring of their obligation to total disarmament, enshrined under the now 46year-old Nuclear Non-Proliferation Treaty.

Third, Britain's increasingly multicultural nature should be treated not as a threat to its militarism, but as the basis of its new internationalism. The UK could carve out a new role for itself as a diplomatic hub, specialising in conflict and dispute resolution, bringing excluded parties into dialogue, and drawing on the increasingly international

\footnotetext{
${ }^{20}$ For reseach on how this can be done, see Campaign Against Arms Trade, "Arms to Renewables: Work for the Future", October 2014, https://www.caat.org.uk/campaigns/arms-to-renewables/armsto-renewables-background-briefing.pdf

${ }^{21}$ Bulletin of the Atomic Scientists, 'Press release: It is now 3 minutes to midnight', 22 January 2015 http://thebulletin.org/press-release/press-release-it-now-3-minutes-midnight7950
} 
character of British society for language skills and broader knowledge and understanding of the rest of the world.

Fourth, the size of the UK military should be sharply reduced but also refocused, away from intercontinental power projection and towards genuine national defence and contributions to UN peacekeeping missions. Credibility to perform the latter task, as well as a potential new role as a diplomatic hub, would require a more neutral posture overall, and a sense of international relationships being based firmly in cooperation and trade rather than the British state's capacity for brute force. (This would mean either revising Britain's role within NATO, or leaving altogether if that were unworkable.)

Finally, Britain should become a serious champion of international economic justice. Aid would form one part of this (though current programmes leave much to be desired), but the main focus should be using Britain's clout in the IMF, World Bank and WTO to push for real policy autonomy for states in the global south to pursue their own strategies outside of neoliberal prescriptions, if that is their choice. As well as being a way of addressing poverty and inequality, and tackling global security issues at their root, this would also earn Britain considerable goodwill in those parts of the world

The case for these policies, or policies like them, can be made to the wider public in clear, straightforward and common sense language, presented as a departure from a failed status quo - and as sensible rather than radical. For politically active and conscious people across the entire left-hand side of the spectrum, these policies could form a realistic and optimistic vision and an attractive set of goals. A new approach calm, mature, dialogue-based, flexible, responsive to new information and new conditions, focused on real problems - can be contrasted with an out-of-date and outof-touch insistence on maintaining patterns of failure, born of pride and dogmatism.

Some of the opposition to such policies will be articulated in 'patriotic' terms, but it would be wrong to mirror such language with a 'me-too' jingoism of the left. Instead, one might speak of taking pride in our country in an honest, self-critical sense, rather than being reflexively proud of our country irrespective of what the facts are. An enlightened society reflects honestly on its experiences, corrects mistakes, atones for misdeeds, and embraces opportunities for rebirth and rejuvenation. The policies above suggest some of the ways in which such opportunities could be taken.

Whether or not recent developments in the British Labour Party render it capable of articulating a counter-narrative along the lines laid out above, the task of doing so is an urgent one. This is particularly true given the severity of the environmental crisis, of the crisis in the Middle East, and, on the latter of these, the capacity of the British state to do further damage. The opportunity that now arises to challenge the hegemonic discourse is, needless to say, one that can only be taken through a broad, collective effort. The above is offered merely as a starting point.

David Wearing is researching for a $\mathrm{PhD}$ on Britain's relationship with Saudi Arabia and the Gulf states at the School of Oriental and African Studies, where he teaches courses on Middle East Politics and International Political Economy. He sits on the steering committee of Campaign Against Arms Trade. 